\title{
DNA homology between Saccharopolyspora strains and other erythromycin-producing actinomycetes
}

\author{
Richard Stanzak, Patti Matsushima, Richard H. Baltz and Brigitte E. Schoner* \\ Department of Molecular Genetics, Lilly Research Laboratories, Eli Lilly and Company, Indianapolis, \\ Indiana 46285, USA
}

(Received 2 January 1990; revised 25 April 1990; accepted 8 May 1990)

\begin{abstract}
The macrolide antibiotic erythromycin is produced by different genera of the Actinomycetales, including strains of Saccharopolyspora, Arthrobacter, Micromonospora and possibly Streptomyces. Erythromycin is also produced by several unclassified strains, four of which could be assigned to the genus Saccharopolyspora on the basis of bacteriophage host specificity. We used cloned erythromycin biosynthetic and resistance genes from Saccharopolyspora erythraea as hybridization probes to determine if the DNA sequences encoding these genes are conserved in different genera. Our results indicated strong hybridization to genomic restriction fragments from strains that were assigned to the genus Saccharopolyspora, and weak hybridization to DNA from strains which produce erythromycin or other macrolides but belong to other genera.
\end{abstract}

\section{Introduction}

Erythromycin A is a clinically important macrolide antibiotic composed of a 14-membered lactone ring (erythronolide) and two sugars, desosamine and cladinose. Erythromycin A was first isolated by McGuire et al. (1952) from cultures of Saccharopolyspora erythraea (formerly Streptomyces erythraeus; Labeda, 1987), a strain that was subsequently used in many laboratories for studies on the genetics and biochemistry of erythromycin production (Seno \& Hutchinson, 1986). Erythromycin biosynthetic genes from Sap. erythraea have been cloned and expressed in Streptomyces lividans (Stanzak et al., 1986); they are located together with the erythromycin resistance gene $(\mathrm{ermE})$ on a $35 \mathrm{~kb}$ DNA fragment. Specific genes have been mapped in this region by Donadio et al. (1989), Weber \& Losick (1988) and Weber et al. (1989).

The erythromycin resistance gene ermE encodes a ribosomal RNA methylase that also gives resistance to other macrolide-lincosamide-streptogramin-B-type (MLS-type) antibiotics (Thompson et al., 1982; Skinner et al., 1983). A related MLS resistance gene from Arthrobacter (ermA) has been cloned (Roberts et al., 1985), based on DNA sequence similarity between ermE

Abbreviations: MLS, macrolide-lincosamide-streptogramin B; TS broth, trypticase soy broth. and ermA. Although other MLS-resistance genes isolated from bacilli, streptococci and staphylococci do not possess comparable DNA sequence similarities (Gryczan et al., 1984), many of these resistance genes (including ermE and ermA) exhibit substantial similarity at the amino acid level, an observation consistent with the proposal that antibiotic resistance genes may have evolved in antibiotic-producing actinomycetes and were subsequently transferred to other micro-organisms (Benveniste $\&$ Davies, 1973).

The micro-organisms that produce erythromycin (and hence are also resistant to erythromycin) include members of several taxonomically distinct genera of the Actinomycetales (e.g. Saccharopolyspora, Arthrobacter, Micromonospora and possibly Streptomyces; see Bowen et al., 1989; Labeda, 1987; and Stackebrandt et al., 1983, for taxonomic relationships), which typically contain a $\mathrm{G}+\mathrm{C}$ content of around $70 \mathrm{~mol} \%$. We have been interested in determining the extent to which erythromycin biosynthetic and resistance genes are conserved in these diverse micro-organisms, and whether they show homology to genes from other macrolide producers, as indicated by Southern hybridization with cloned erythromycin biosynthetic and resistance genes. Our results show that erythromycin biosynthetic and resistance gene sequences are not highly conserved in taxonomically distinct strains of actinomycetes, and do not show extensive homology to DNA from other macrolide producers. 


\section{Methods}

Strains and bacteriophages. Bacterial strains used in this study are listed in Table 1. Of the bacteriophages, $\phi$ SE6 and $\phi$ SE6 9 were isolated from Sap. erythraea (Grund \& Hutchinson, 1987); FP4, FP22, FP46, FP50 and FP62 are broad-host-range streptomycete bacteriophages (Cox \& Baltz, 1984; Matsushima \& Baltz, 1989); and OP1, OP2, OP3, OP4, OP5, OP6, OP15 and OP16 were isolated on Amycolatopsis orientalis (K. Cox, M. McHenney \& R. H. Baltz, unpublished). $\phi$ SE6 and $\phi$ SE69 were propagated on Sap. erythraea and dilutions of the phage were plated on mycelial fragments generated by uitrasound (Baltz, 1978) from strains listed in Table 2 as described by Cox \& Baltz (1984). The plating efficiencies of $\phi$ SE6 and $\phi$ SE6 9 were calculated relative to plating efficiencies on Saccharopolyspora hirsuta ATCC 27875. The FP phages and the OP phages were propagated and plated on $S$. griseofuscus and A. orientalis, respectively, as described by Cox \& Baltz (1984).

Media and culture conditions. The bacterial cultures were grown in TS broth (Baltz, 1978). The media and procedures for preparing phage stocks and phage platings were those described by Cox \& Baltz (1984). Erythromycin resistance was determined by plating mycelial fragments after ultrasonic treatment (Baltz, 1978) on TS agar plates containing $1 \mathrm{mg}$ erythromycin $\mathrm{ml}^{-1}$. Erythromycin production was verified by growing the cultures at $30^{\circ} \mathrm{C}$ in modified S medium (Stanzak et al., 1986), except for strain A37609, which was grown in PNS medium. PNS medium contained (per litre): $25 \mathrm{~g}$ glucose; $10 \mathrm{~g}$ corn starch; $5 \mathrm{~g}$ Bacto-peptone (Difco); $4 \mathrm{~g} \mathrm{NZ}$ amine A (Sheffield Products); $5 \mathrm{~g}$ black strap molasses; $0.5 \mathrm{~g} \mathrm{MgSO}_{4} .7 \mathrm{H}_{2} \mathrm{O} ; 2 \mathrm{~g} \mathrm{CaCO}_{3}$ and $2 \mathrm{ml}$ Czapek's mineral stock. The mineral stock contained (per litre: $100 \mathrm{~g} \mathrm{KCl} ; 100 \mathrm{~g}$ $\mathrm{MgSO}_{4} \cdot 7 \mathrm{H}_{2} \mathrm{O}$ and $2 \mathrm{~g} \mathrm{FeSO}_{4} .7 \mathrm{H}_{2} \mathrm{O}$. After $3 \mathrm{~d}$ of growth, the broths were adjusted to $\mathrm{pH} 8.5$ and extracted twice with ethyl acetate; the extracts were concentrated approximately fivefold by evaporation. Samples (about $25 \mu$ l) of the concentrated extracts were spotted onto aluminium-backed cellulose plates (EM Reagents) and the chromatograms developed in $\mathrm{K}_{2} \mathrm{HPO}_{4} /$ ethanol $/ \mathrm{H}_{2} \mathrm{O}(1 \cdot 74: 3 \cdot 0: 95$, w/v/v). The TLC plates were air-dried, and placed onto TS agar plates seeded with Micrococcus luteus ATCC 9341. The chromatograms were removed and the TS agar plates were incubated at $34^{\circ} \mathrm{C}$ for $16-24 \mathrm{~h}$ and examined for antibiotic zones.

Southern hybridization analysis. Total DNA was extracted according to the procedure of Chater et al. (1984) from $10 \mathrm{ml}$ cultures grown in TS broth for $3 \mathrm{~d}$ at $30^{\circ} \mathrm{C}$. The DNA was digested with restriction enzymes in buffers recommended by the manufacturers (New England Biolabs or Boehringer Mannheim). Agarose gel electrophoresis and Southern hybridization analysis were performed in $50 \%(\mathrm{v} / \mathrm{v})$ formamide and $5 \times$ SSPE $\left(1 \times\right.$ SSPE $=9 \mathrm{~mm}-\mathrm{NaCl}, 0.5 \mathrm{~mm}-\mathrm{NaH}_{2} \mathrm{PO}_{4}, 0.05 \mathrm{~mm}-\mathrm{EDTA}$, $\mathrm{pH} 7.7)$ at $42^{\circ} \mathrm{C}$. The filters were washed in $0.1 \times \mathrm{SSPE}$ at $60^{\circ} \mathrm{C}$ as described by McHenney \& Baltz (1988). Under these conditions, hybridization can be detected with DNA fragments of approximately $80 \%$ similarity or greater.

\section{Results and Discussion}

\section{Bacteriophage host range analysis}

Several different bacteriophages, which form plaques on species of Streptomyces, Amycolatopsis or Saccharopolyspora, were used to characterize the strains listed in Table 1. $\phi$ SE6 and $\phi$ SE69 were reported to form plaques on Sap. erythraea (formerly $S$. erythraeus) but not on Streptomyces spp. (Grund \& Hutchinson, 1987). Both $\phi$ SE6 and $\phi$ SE69 plated very efficiently on Sap. erythraea (Table 2), and on Saccharopolyspora hirsuta NRRL B-5792. Phage $\phi$ SE69 also plated on Sap. hirsuta NRRL 12045, but at a low efficiency. Neither $\phi$ SE6 nor $\phi$ SE69 plated on the strains of Streptomyces, Amycolatopsis, Actinoplanes, Arthrobacter and Micromonospora listed in Table 1 . These results indicate that the host range of $\phi$ SE6 and $\phi$ SE69 is limited to the genus Saccharopolyspora. Four of the seven unclassified erythromycinproducing strains (A57583, A51740, A51741 and A51742) also supported plaque formation by $\phi$ SE6 and $\phi$ SE69 (Table 2). We then tested these strains for plaque formation by five broad-host-range Streptomyces phages (FP4, FP22, FP46, FP50 and FP62). As expected from previous studies (Cox \& Baltz, 1984), plaque formation was observed on Streptomyces ambofaciens, Streptomyces griseofuscus and Streptomyces lividans, but not on Sap. erythraea (not shown). None of the unclassified strains supported plaque formation by any of these five phages. The unclassified strains were also tested for plaque formation by eight bacteriophages isolated on Amycolatopsis orientalis. These phages formed plaques on both Amycolatopsis species tested, but not on any of the other strains listed in Table 1, including the unclassified erythromycin producers. The bacteriophage host range data are therefore consistent with the reassignment of $S$. erythraeus to the genus Saccharopolyspora (Labeda, 1987); further, four of the unclassified erythromycinproducing strains (A57583, A51740, A51741 and A51742) can be tentatively assigned to the genus Saccharopolyspora.

\section{Southern hybridization analysis of erythromycin- producing strains}

In Sap. erythraea, erythromycin biosynthetic genes are clustered on the chromosome and linked to the erythromycin resistance gene ermE (Stanzak et al., 1986; Weber et al., 1985, 1989; Weber \& Losick, 1988; Donadio et al., 1989). To determine the extent of sequence relatedness among the erythromycin biosynthetic genes in different strains producing erythromycin, we used cloned erythromycin biosynthetic genes from Sap. erythraea as a hybridization probe.

The strains we chose for the analysis included classified strains (e.g. Sap. erythraea) and several unclassified strains isolated from soils collected at various locations around the world (see Table 1). Genomic DNA was isolated and digested with BamHI and the resulting restriction fragments were separated by agarose gel electrophoresis and analysed by Southern hybridization using plasmid pKC488 as a probe. This plasmid was isolated from a genomic library of Sap. erythraea (Stanzak et al., 1986) and carries erythromycin 
Table 1. Actinomycete strains used

\begin{tabular}{|c|c|c|c|}
\hline Strain & $\begin{array}{c}\text { Source or } \\
\text { geographical origin }\end{array}$ & Antibiotic produced & Reference(s) \\
\hline Saccharopolyspora erythraea & NRRL 2338* & Erythromycin $\dagger$ & $\begin{array}{l}\text { Labeda (1987); Seno \& } \\
\text { Hutchinson (1986) }\end{array}$ \\
\hline Saccharopolyspora hirsuta & NRRL B-5792‡ & Aminoglycoside KA-5685 & Labeda (1987) \\
\hline Saccharopolyspora hirsuta & NRRL 12045 & Nargenicin Al & Whaley et al. (1980) \\
\hline Streptomyces ambofaciens & ATCC 15154 & Spiramycin & Matsushima \& Baltz (1985) \\
\hline Streptomyces griseofuscus & ATCC 23916 & Bundlin & Cox \& Baltz (1984) \\
\hline Streptomyces lividans TK 23 & NRRL 15826 & Actinorhodin & Hopwood et al. (1984) \\
\hline Amycolatopsis orientalis & ATCC 19795 & Vancomycin & $\begin{array}{c}\text { Barna \& Williams (1984); } \\
\text { Lechevalier et al. }(1986)\end{array}$ \\
\hline Amycolatopsis sp. & NRRL 8156 & Glycopeptide A35512 & $\begin{array}{c}\text { Barna \& Williams (1984); } \\
\text { Lechevalier et al. (1986) }\end{array}$ \\
\hline Actinoplanes teichomyceticus & ATCC 31121 & Teichoplanin & Hunt et al. (1984) \\
\hline Arthrobacter sp. & NRRL 3381 & Erythromycin $\dagger$ & Roberts et al. (1985) \\
\hline $\begin{array}{l}\text { Micromonospora rosaria } \\
\text { Micromonospora } \mathrm{sp} .1225\end{array}$ & $\begin{array}{l}\text { ATCC } 29337 \\
\text { Schering }\end{array}$ & $\begin{array}{l}\text { Rosaramicin } \\
\text { Erythromycin }\end{array}$ & $\begin{array}{l}\text { Ganguly et al. (1982) } \\
\text { Seno \& Hutchinson (1986) }\end{array}$ \\
\hline A $37609 \S$ & Palestine & Erythromycin $\dagger$ & This report \\
\hline A57583§ & Barbados & Erythromycin $\dagger$ & This report \\
\hline A51735§ & Kenya & Erythromycin $\dagger$ & This report \\
\hline A $51740 \S$ & Kenya & Erythromycin $\dagger$ & This report \\
\hline A51741§ & Kenya & Erythromycin $\dagger$ & This report \\
\hline A51742§ & Kenya & Erythromycin $\dagger$ & This report \\
\hline A51744§ & India & Erythromycin $\dagger$ & This report \\
\hline
\end{tabular}

* Formerly Streptomyces erythraeus.

$\dagger$ Erythromycin production and resistance to erythromycin were verified as described in Methods.

$\$$ Type strain

$\S$ Not formally identified.

Table 2. Efficiency of plating of Sap. erythraea phages $\phi S E 6$ and $\phi S E 69$ on erythromycin-producing and other actinomycetes

\begin{tabular}{|c|c|c|}
\hline \multirow[b]{2}{*}{ Strain } & \multicolumn{2}{|c|}{$\begin{array}{c}\text { Relative efficiency of } \\
\text { plating }\end{array}$} \\
\hline & $\phi$ SE6 & $\phi$ SE69 \\
\hline $\begin{array}{l}\text { Saccharopolyspora erythraea } \\
\text { Saccharopolyspora hirsuta (NRRL B-5792) } \\
\text { Saccharopolyspora hirsuta (NRRL 12045) }\end{array}$ & $\begin{array}{c}5 \times 10^{-1} \\
1 \cdot 0 \\
<10^{-9}\end{array}$ & $\begin{array}{l}10^{-1} \\
1 \cdot 0 \\
10^{-7}\end{array}$ \\
\hline $\begin{array}{l}\text { Streptomyces ambofaciens } \\
\text { Streptomyces griseofuscus } \\
\text { Streptomyces lividans } \text { TK } 23\end{array}$ & $\begin{array}{l}<10^{-9} \\
<10^{-9} \\
<10^{-9}\end{array}$ & $\begin{array}{l}<10^{-9} \\
<10^{-9} \\
<10^{-9}\end{array}$ \\
\hline $\begin{array}{l}\text { Amycolatopsis orientalis } \\
\text { Amycolatopsis } \mathrm{sp} .\end{array}$ & $\begin{array}{l}<10^{-9} \\
<10^{-9}\end{array}$ & $\begin{array}{l}<10^{-9} \\
<10^{-9}\end{array}$ \\
\hline Actinoplanes teichomyceticus & $<10^{-9}$ & $<10^{-9}$ \\
\hline Arthrobacter sp. & $<10^{-9}$ & $<10^{-9}$ \\
\hline $\begin{array}{l}\text { Micromonospora rosaria } \\
\text { Micromonospora } \text { sp. } 71-1225\end{array}$ & $\begin{array}{l}<10^{-9} \\
<10^{-9}\end{array}$ & $\begin{array}{l}<10^{-9} \\
<10^{-9}\end{array}$ \\
\hline $\begin{array}{l}\text { A37609 } \\
\text { A57583 } \\
\text { A51735 } \\
\text { A5 } 51740 \\
\text { A51741 } \\
\text { A51742 } \\
\text { A5 } 51744\end{array}$ & $\begin{aligned} & <10^{-9} \\
2 & \times 10^{-5} \\
& <10^{-9} \\
4 & \times 10^{-3} \\
3 & \times 10^{-3} \\
3 & \times 10^{-8} \\
& <10^{-9}\end{aligned}$ & $\begin{array}{r}<10^{-9} \\
2 \times 10^{-3} \\
<10^{-9} \\
10^{-2} \\
10^{-1} \\
10^{-6} \\
<10^{-9}\end{array}$ \\
\hline
\end{tabular}

biosynthetic and resistance genes on a $35 \mathrm{~kb}$ DNA insert (see Fig. 1). The erythromycin resistance gene $(\mathrm{erm} E)$ is located on a $3 \mathrm{~kb} \mathrm{BamHI}$ restriction fragment contained within the $35 \mathrm{~kb}$ insert in pKC488. As shown in Fig. $2(a)$, intense hybridization was observed between pKC488 and several genomic BamHI restriction fragments from six of the erythromycin-producing unclassified strains (lanes 2-5, 7 and 8). Weaker hybridization to fewer genomic restriction fragments was observed between pKC488 and DNA from strain A37609 (lane 6), Arthrobacter sp. (lane 9) and Micromonospora sp. (Fig. $2 b$, lane 2 ), and very weak hybridization to one or two restriction fragments was observed with DNA from the Sap. hirsuta strains. No hybridization was observed to $S$. lividans DNA (Fig. 2a, lane 11). To investigate whether DNA sequences similar to the resistance gene ermE exist in the erythromycin-producing strains, we treated the hybridization filters to remove the radiolabelled probe (pKC488) and rehybridized the filter-bound DNA with pKC407, a plasmid containing the coding sequence for ermE on a $1.8 \mathrm{~kb}$ Bam $\mathrm{HI}-$ PstI restriction fragment. As expected, pKC407 hybridized to a $3 \mathrm{~kb}$ BamHI restriction fragment from the Sap. erythraea chromosome (Fig. $3 a$, lane 1). The plasmid also hybridized to a $3 \mathrm{~kb} \mathrm{BamHI}$ 


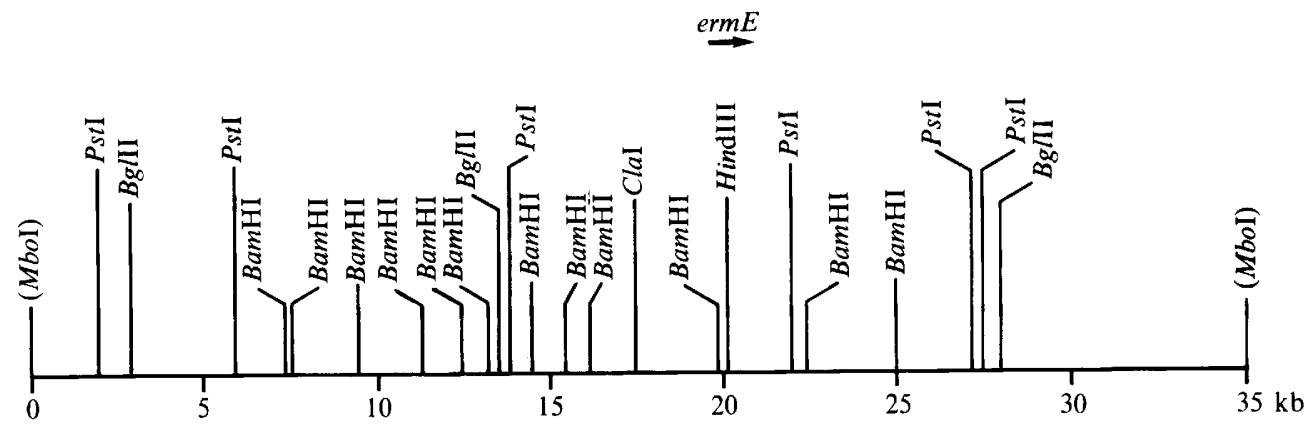

Fig. 1. Restriction map of the $35 \mathrm{~kb}$ insert in pKC488.
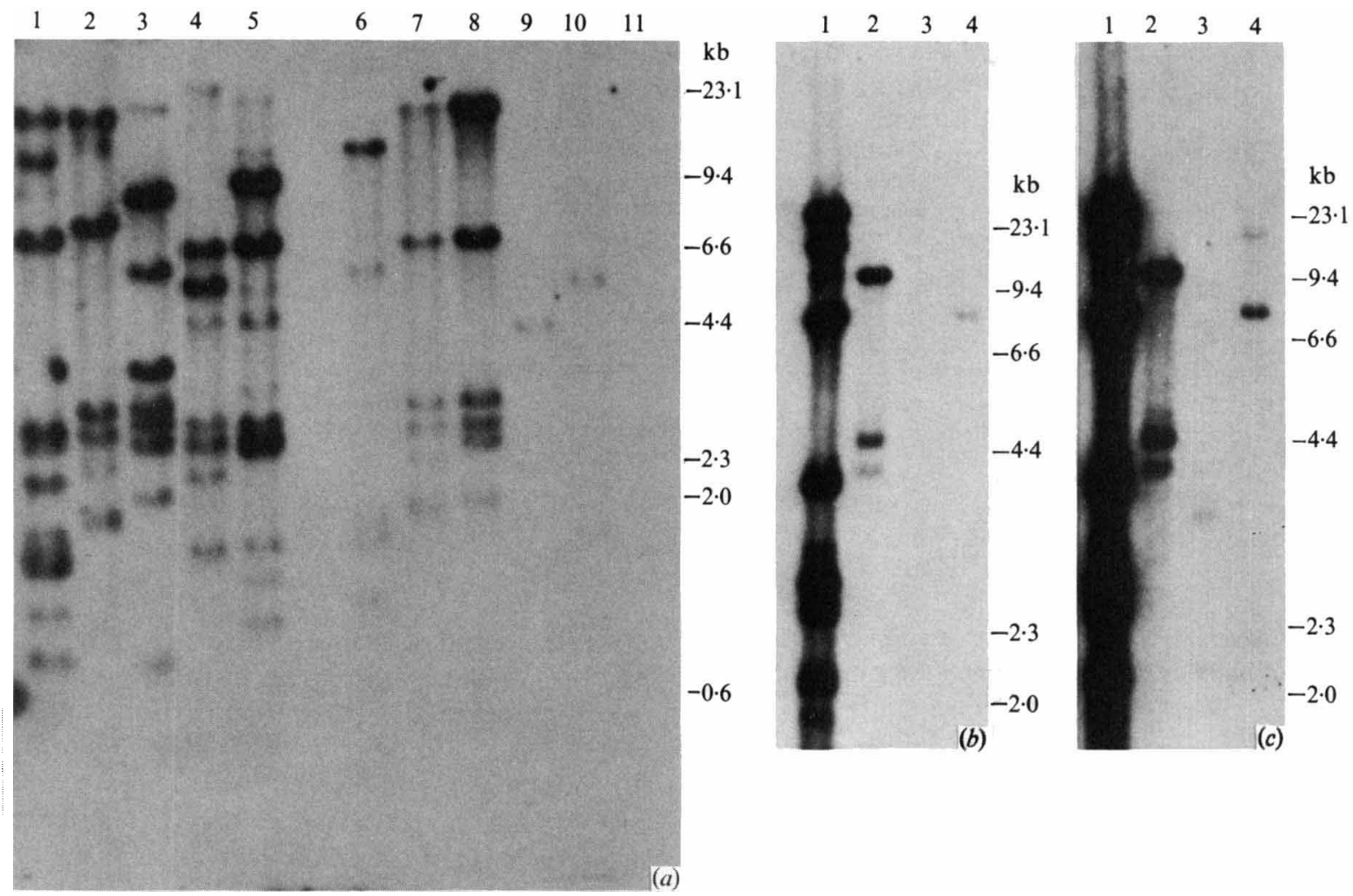

Fig. 2. Southern hybridization analysis of genomic restriction fragments generated with $B a m H I$ and hybridized with plasmid pKC488. (a) Genomic DNA from: Sap. erythraea (lane 1); A51583 (lane 2); A51741 (lane 3); A51735 (lane 4); A51744 (lane 5); A37609 (lane 6); A51742 (lane 7); A51740 (lane 8); Arthrobacter sp. (lane 9); S. griseofuscus (lane 10); S. lividans TK23 (lane 11). (b) Genomic DNA from: Sap. erythraea (lane 1); Micromonospora sp. (lane 2); Sap. hirsuta ATCC 27875 (lane 3); Sap. hirsuta NRRL 12045 (lane 4). (c) is a longer exposure of the film shown in $(b)$. A HindIII digest of $\lambda$ DNA was used as a standard.

restriction fragment from genomic DNA of the five unclassified strains that hybridized strongly with pKC488 (Fig. 3a, lanes 2-5, 7, 8); however pKC407 did not hybridize to DNA from strains that hybridized weakly with pKC488, including A37609, Arthrobacter sp., S. griseofuscus, Micromonospora sp., and the two Sap. hirsuta strains, and did not hybridize to DNA from $S$. lividans.

To determine whether the strong hybridization between the probes (pKC488 and $\mathrm{pKC}$ 407) and the genomic restriction fragments from the six unclassified strains is confined to the region containing the erythromycin biosynthetic and resistance genes, we repeated the Southern hybridization analysis with pKC491, a cosmid from the Sap. erythraea DNA library containing a $35 \mathrm{~kb}$ DNA insert that does not cross-hybridize with the DNA insert in pKC488. Using pKC491 as a probe, we observed strong hybridization with DNA from five of the unclassified strains (A51583, A51741, A51735, A51744 and A51740), weak hybridization with DNA from A51742 and no hybridization with DNA from A37609, S. griseofuscus, S. lividans, Micromonospora $\mathrm{sp.}$ 

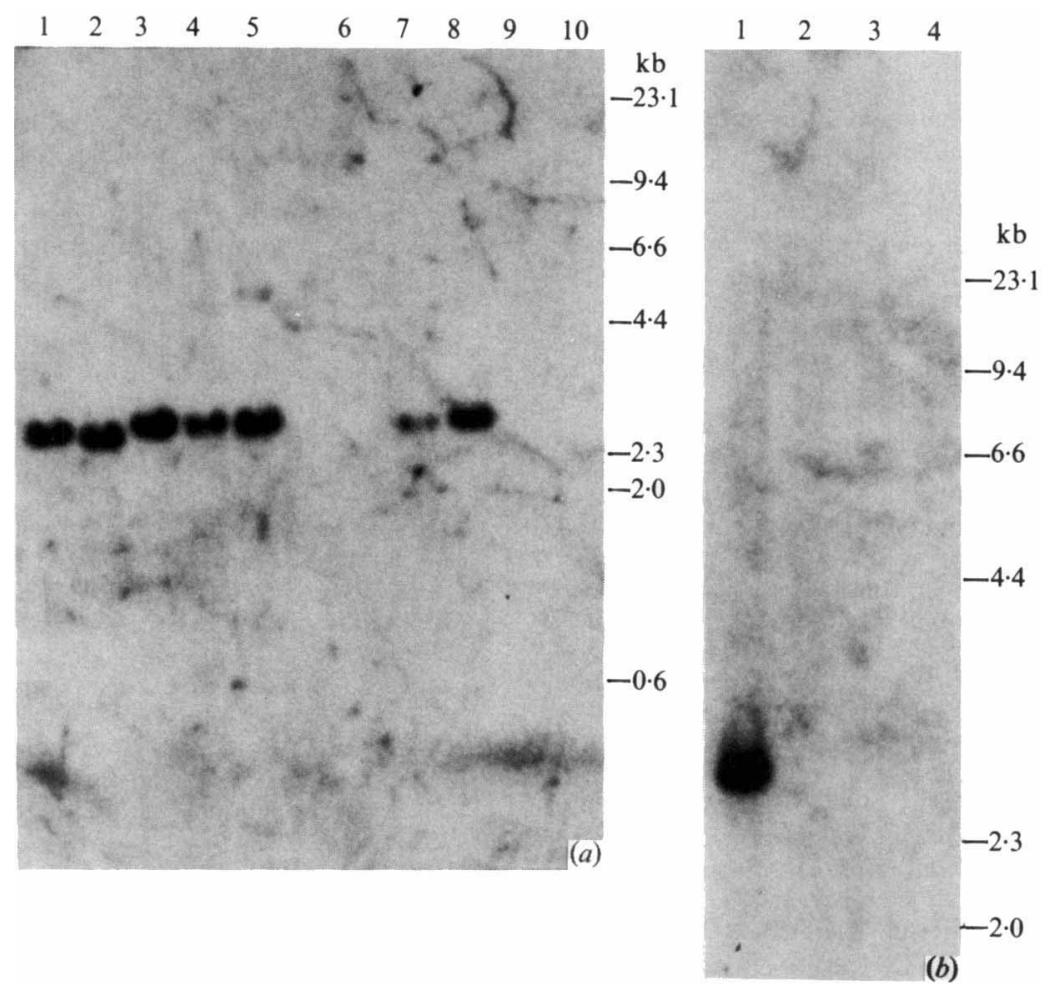

Fig. 3. Southern hybridization analysis of genomic restriction fragments hybridized with the erythromycin resistance gene ermE. The blots shown in Fig. 2 were treated to remove the hybridization probe and rehybridized with pKC408. (a) Genomic DNA from: Sap. erythraea (lane 1); A51583 (lane 2); A51741 (lane 3); A51735 (lane 4); A51744 (lane 5); A37609 (lane 6); A51742 (lane 7); A51740 (lane 8); Arthrobacter sp. (lane 9); S. griseofuscus (lane 10). (b) Genomic DNA from: Sap. erythraea (lane 1); Micromonospora sp. (lane 2); Sap. hirsuta ATCC 27875 (lane 3); Sap. hirsuta NRRL 12045 (lane 4). A HindIII digest of $\lambda$ DNA was used as a standard.

or the two Sap. hirsuta strains (data not shown). These results suggest that the five unclassified strains are more closely related to Sap. erythraea than to the two other members of the genus Saccharopolyspora. However, these five strains are not identical since the lengths of the hybridizing restriction fragments generated with BamHI and $X h o I$ varied with each strain.

Based on these results, we could place the erythromycin-producing strains into two groups. Members of one group possess sequences that hybridize strongly with the erythromycin biosynthetic gene probe, and with a random probe (pKC491) from the Sap. erythraea library, indicating that these strains are closely related to Sap. erythraea. The bacteriophage typing also suggested that at least four of these strains are members of the genus Saccharopolyspora. Members of the other group possess sequences that hybridize weakly with the erythromycin biosynthetic gene probe, and not at all with the random probe, pKC491. The regions that hybridize with the erythromycin biosynthetic gene probe appear to be confined to a small number of restriction fragments which do not include those encoding the erythromycin resistance genes. The lack of extensive DNA sequence homology among diverse erythromycin-producing strains suggests several evolutionary possibilities: (1) that erythromycin biosynthetic genes evolved before the divergence of actinomycete genera; (2) that these genes were transferred horizontally between certain genera early on the evolutionary time scale; or (3) that all or parts of the erythromycin pathway genes evolved more than once. In the case of $\beta$-lactam antibiotics that are produced by several species of Streptomyces and by several genera of fungi, there is evidence to suggest that the genes evolved in a streptomycete and were transferred around 370 million years ago to a fungal progenitor of Aspergillus, Cephalosporium and Penicillium (Weigel et al., 1988). More detailed studies on the structural organization of erythromycin biosynthetic genes in different actinomycetes, and DNA sequence analysis of several specific genes cloned from taxonomically distinct micro-organisms should provide additional insights into the evolution of erythromycin biosynthetic genes.

We thank P. Solenberg for unpublished information on erythromycin-producing strains isolated at Eli Lilly and Company, C. Nash and D. A. Hopwood for providing strains, and B. Fogleman for typing the manuscript. 


\section{References}

BALTZ, R. H. (1978). Genetic recombination in Streptomyces fradiae by protoplast fusion and cell regeneration. Journal of General Microbiology 107, 93-102.

Barna, J. C. J. \& Williams, D. H. (1984). The structure and mode of action of glycopeptide antibiotics of the vancomycin group. Annual Review of Microbiology 38, 339-357.

BENVENISTE, R. \& DAVIS, J. (1973). Aminoglycoside antibioticinactivating enzymes in actinomycetes similar to those present in clinical isolates of antibiotic-resistant bacteria. Proceedings of the National Academy of Sciences of the United States of America 70, 2276-2280.

Bowen, T., Stackenbrandt, E., Dorsch, M. \& Embley, T. M. (1989). The phylogeny of Amycolata autotrophica, Kibdelosporangium aridum and Saccharothrix australiensis. Journal of General Microbiology 135, 2529-2536.

Chater, K. F., Hopwood, D. A., Kieser, T. \& Thompson, C. J. (1984). Gene cloning in Streptomyces. Current Topics in Microbiology and Immunology 97, 69-95.

Cox, K. L. \& BALTZ, R. H. (1984). Restriction of bacteriophage plaque formation in Streptomyces spp. Journal of Bacteriology 159, 499-504.

Donadio, S., Tuan, J. S., Staver, M. J., Weber, J. M., Paulus, T. J., Maine, G. T., Leung, J. O., Dewitt, J. P., Vara, J. A., Wang, Y.-G., Hutchinson, C. R. \& KaTZ, L. (1989). Genetic studies on erythromycin biosynthesis in Saccharopolyspora erythraea. In Genetics and Molecular Biology of Industrial Microorganisms, pp. 5359. Edited by C. L. Hershberger, S. W. Queener \& G. Hegeman. Washington, DC: American Society for Microbiology.

Ganguly, A. T., Lee, B. K., Liu, Y.-T., Lotvin, J., Sarre, O. \& VAUGHN, R. (1982). Mutasynthesis of 23-O-mycaminosyl-12,13desepoxy-12,13-didehydrorosaramicin from tylosin. Journal of the Chemical Society Chemical Communications 855-857.

Gryczan, T., Israeli-Reches, M., Del Bue, M. \& Dubnau, D. (1984). DNA sequence and regulation of ermD, a macrolidelincosamide-streptogramin B resistance element from Bacillus licheniformis. Molecular and General Genetics 194, 349-356.

GRUND, A. D. \& HUTCHINSON, C. R. (1987). Bacteriophages of Saccharopolyspora erythraea. Journal of Bacteriology 169, 3013-3022. Hopwood, D. A., HintermanN, G., Kieser, T. \& Wright, H. M. (1984). Integrated DNA sequences in three streptomycetes from related autonomous plasmids after transfer to Streptomyces lividans. Plasmid 11, 1-16.

Hunt, A. H., Molloy, R. M., Occolowitz, J. L., Marconi, G. G. \& DEBONo, M. (1984). Structure of the major glycopeptide of the teicoplanin complex. Journal of the American Chemical Society 106 , $4891-4895$.

LabedA, D. P. (1987). Transfer of the type strain of Streptomyces erythraeus (Waksman 1923) Waksman and Henrici 1948 to the genus Saccharopolyspora Lacey and Goodfellow 1975 as Saccharopolyspora erythraea sp. nov., and designation of a neotype strain for Streptomyces erythraeus. International Journal of Systematic Bacteriology 37, 19-22.

LeCheValier, M. P., Prauser, H., Labeda, D. P. \& Ruan, J.-S. (1986). Two new genera of nocardioform actinomycetes: Amycolata gen. nov. and Amycolatopsis gen. nov. International Journal of Systematic Bacteriology 36, 29-37.

Matsushima, P. \& BalTZ, R. H. (1985). Efficient plasmid transformation of Streptomyces ambofaciens and Streptomyces fradiae protoplasts. Journal of Bacteriology 163, 180-185.

Matsushima, P. \& BaLTz, R. H. (1989). Streptomyces lipmanii expresses two restriction systems that inhibit plasmid transformation and bacteriophage plaque formation. Journal of Bacteriology 171, 31283132 .

McGuire, J. M., Bunch, R. L., Anderson, R. C., BoAz, H. E., FLYNN, E. H., POWELL, H. M. \& SMITH, J. W. (1952). Ilotycin, a new antibiotic. Antibiotics and Chemotherapy 2, 281-283.

MCHENNEY, M. A. \& BALTZ, R. H. (1988). Transduction of plasmid DNA in Streptomyces spp. and related genera by bacteriophage FP43. Journal of Bacteriology 170, 2276-2282.

Roberts, A. N., Hudson, G. S. \& BRenNer, S. (1985). An erythromycin-resistance gene from an erythromycin-producing strain of Arthrobacter sp. Gene 35, 259-270.

Seno, E. T. \& HutChinson, C. R. (1986). The biosynthesis of tylosin and erythromycin: model systems for studies of the genetics and biochemistry of antibiotic formation. In The Bacteria, vol. 9, Antibiotic-producing Streptomyces, pp. 231-279. Edited by L. E. Day \& S. W. Queener. New York: Academic Press.

SKINNER, R. H., CUNDLIFFE, E. \& SCHMIDT, F. J. (1983). Site of action of a ribosomal RNA methylase responsible for resistance to erythromycin and other antibiotics. Journal of Biological Chemistry 258, $12702-12706$

Stackebrandt, E., Ludwig, W., Seewaldt, E. \& Schleifer, K.-H (1983). Phylogeny of sporeforming members of the order Actinomycetales. International Journal of Systematic Bacteriology 33, 173-180.

Stanzak, R., Matsushima, P., Baltz, R. H. \& Rao, R. N. (1986) Cloning and expression in Streptomyces lividans of clustered erythromycin biosynthesis genes from Streptomyces erythreus. Biotechnology 4, 229-232.

THOMPSON, C. J., KiEser, T., WARD, J. M. \& Hopwood, D. A. (1982) Physical analysis of antibiotic resistance genes from Streptomyces and their use in vector construction. Gene 20, 51-62.

WEBER, J. M. \& Losick, R. (1988). The use of a chromosomal integration vector to map erythromycin resistance and production genes in Saccharopolyspora erythraea ( Streptomyces erythreus). Gene 68, $173-180$

Weber, J. M., Wierman, C. K. \& Hutchinson, C. R. (1985). Genetic analysis of erythromycin production in Streptomyces erythreus. Journal of Bacteriology 164, 425-433.

WEBER, J. M., SCHONER, B. \& Losick, R. (1989). Identification of a gene required for the terminal step in erythromycin A biosynthesis in Saccharopolyspora erythraea ( Streptomyces erythreus). Gene 75, 235241

Weigel, B. J., Burgett, S. G., Chen, V. J., Skatrud, P. L., Frolik, C. A., QueEner, S. W. \& Ingolia, T. D. (1988). Cloning and expression in Escherichia coli of isopenicillin $\mathrm{N}$ synthetase genes from Streptomyces lipmanii and Aspergillus nidulans. Journal of Bacteriology 170, 3817-3826.

Whaley, H. A., Chidester, C. G., Mizsak, S. A. \& Wnuk, R. J. (1980). Nodusmicin: the structure of a new antibiotic. Tetrahedron Letters 21, 3659-3662. 